\title{
JCSHM: invaluable resource for practice of civil structural health monitoring
}

\author{
Farhad Ansari $^{1}$
}

Published online: 2 February 2018

(C) Springer-Verlag GmbH Germany, part of Springer Nature 2018

The Journal of Civil Structural Health Monitoring (JCSHM) has just turned 8 years old. JCSHM has made it easy for researchers and practitioners to find specific structural health monitoring-related articles for use in their research and practice of CSHM. Several issues of the journal have been dedicated to specific topical areas. For example, issue number 1 of volume 6 features a number of state-of-the-art articles covering interesting topics, such as wireless sensors, monitoring of complex and large structures, bridge-vehicle interactions, and weigh-in-motion sensors. The articles in issue number 5 of volume 5 are dedicated to real-time condition assessment of tunnels, health monitoring of soil strata during coal mining, monitoring the deformation of rock formations, detection of soil subsidence, and online monitoring of landslides.

In addition to traditional areas of monitoring, articles published in JCSHM cover applications to a broader spectrum of infrastructure systems. Issue number 2 of volume 5 contains a number of articles pertaining to the monitoring of timber structures. In the same volume, issue number 5 covers the articles corresponding to the monitoring of geo-infrastructure systems. 2018 will be another great year for the journal. We have lined up a number of articles on the specific topical areas pertaining to monitoring of heritage structures and structural health monitoring of cable-supported bridges.

\footnotetext{
Farhad Ansari

fansari@uic.edu

1 Chicago, USA
}

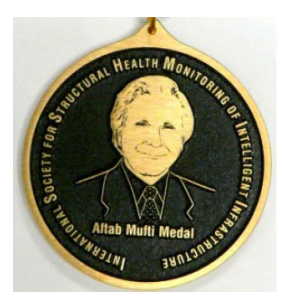

JCSHM recognizes excellence and awards the authors of the best paper from each volume with the Aftab Mufti medal. The medal has been awarded eight times since its inception in December 2011. The Aftab Mufti Medal honors the service, dedication, and lifetime achievements of Dr. Aftab Mufti, cofounder and the first president of ISHMII.

The committee responsible for the selection of the best paper published in volume 5 of the journal was chaired by Dr. Paolo Clemente, and the membership included Professors Ho-Kyong Kim, Didem Ozevin, Zhou Zhi, and Dr. Francisco Carrion-Viramontes. The committee responsible for selection of the best paper in volume 6 was chaired by Professor Toshiyuki Oshima, and the membership included Professors Alper Ilki, Yi-Qing Ni, Ian Smith, and Trip Shenton. The two committees followed a rigorous procedure, and came up with the winners. I am grateful to their hard work and diligence in serving the journal. For volume 5, the paper authored by M. Malekzadeh, G. Atia, and F. N. Catbas was the winner of Aftab Mufti medal. This paper is entitled as, "Performancebased structural health monitoring through an innovative hybrid data interpretation framework". This paper appeared in issue number 3 of volume 5 on July 2015, pages 287-305. For volume 6, the article authored by R. Betti, M. J. Deeble Sloane, D. Khazem and C. Gatti was selected as the winner of Aftab Mufti medal. This article is entitled as, "Monitoring the structural health of main cables of suspension bridges". It appeared in issue 3 of volume 6 on July of 2016, pages 355-363. Congratulations to the winners of the Aftab Mufti medals.

I sincerely hope that our readers find the articles published in JCSHM useful for their research and practice. I am inviting you to publish your articles in JCSHM, and thank you for playing a crucial role in JCSHM's success.

Farhad Ansari,

Editor-in-Chief 